\title{
V374A KCND3 Pathogenic Variant Associated With Paroxysmal Ataxia Exacerbations
}

Martin Paucar, MD, PhD, * Richard Ågren, MD, PhD, * Tianyi Li, PhD, Simon Lissmats, Åsa Bergendal, PhD, Jan Weinberg, MD, PhD, Daniel Nilsson, PhD, Irina Savichetva, MD, PhD, Kristoffer Sahlholm, PhD, Johanna Nilsson, MD, PhD, and Per Svenningsson, MD, PhD

Neurol Genet 2021;7:e546. doi:10.1212/NXG.0000000000000546

\author{
Correspondence \\ Dr. Paucar \\ martin.paucar-arce@karolinska.se
}

\begin{abstract}
Objective

Ataxia channelopathies share common features such as slow motor progression and variable degrees of cognitive dysfunction. Mutations in potassium voltage-gated channel subfamily D member 3 (KCND3), encoding the $\mathrm{K}+$ channel, $\mathrm{Kv} 4.3$, are associated with spinocerebellar ataxia (SCA) 19, allelic with SCA22. Mutations in potassium voltage-gated channel subfamily C member 3 (KCNC3), encoding another $\mathrm{K}+$ channel, Kv3.3, cause SCA13. First, a comprehensive phenotype assessment was carried out in a family with autosomal dominant ataxia harboring 2 genetic variants in KCNC3 and KCND3. To evaluate the physiological impact of these variants on channel currents, in vitro studies were performed.
\end{abstract}

\section{Methods}

Clinical and psychometric evaluations, neuroimaging, and genotyping of a family (mother and son) affected by ataxia were carried out. Heterozygous and homozygous Kv3.3 A671V and Kv4.3 V374A variants were evaluated in Xenopus laevis oocytes using 2-electrode voltage-clamp. The influence of $\mathrm{Kv} 4$ conductance on neuronal activity was investigated computationally using a Purkinje neuron model.

\section{Results}

The main clinical findings were consistent with adult-onset ataxia with cognitive dysfunction and acetazolamide-responsive paroxysmal motor exacerbations in the index case. Despite cognitive deficits, fluorodeoxyglucose (FDG)-PET displayed hypometabolism mainly in the severely atrophic cerebellum. Genetic analyses revealed the new variant c.1121T>C (V374A) in KCND3 and c.2012T >C (A671V) in KCNC3. In vitro electrophysiology experiments on Xenopus oocytes demonstrated that the V374A mutant was nonfunctional when expressed on its own. Upon equal coexpression of wild-type (WT) and V374A channel subunits, Kv4.3 currents were significantly reduced in a dominant negative manner, without alterations of the gating properties of the channel. By contrast, Kv3.3 A671V, when expressed alone, exhibited moderately reduced currents compared with WT, with no effects on channel activation or inactivation. Immunohistochemistry demonstrated adequate cell membrane translocation of the Kv4.3 V374A variant, thus suggesting an impairment of channel function, rather than of expression. Computational modeling predicted an increased Purkinje neuron firing frequency upon reduced $\mathrm{Kv} 4.3$ conductance.

\section{Conclusions}

Our findings suggest that Kv4.3 V374A is likely pathogenic and associated with paroxysmal ataxia exacerbations, a new trait for SCA19/22. The present FDG PET findings contrast with a previous study demonstrating widespread brain hypometabolism in SCA19/22.
*These authors contributed equally to this work.

From the Department of Clinical Neuroscience (M.P., R.A.., T.L., A..B., J.N., P.S.), Department of Molecular Medicine and Surgery (D.N.), Center for Molecular Medicine (D.N.), and Science for Life Laboratory (D.N.), Karolinska Institutet (S.L., I.S.), Stockholm; Department of Neurology (M.P., J.W., P.S.), Department of Clinical Genetics (D.N.), Department of Nuclear Medicine (I.S.), and Department of Neurophysiology (J.N.), Karolinska University Hospital (R.Å.), Stockholm; Department of Integrative Medical Biology (K.S.), Umeå University; and Department of Medical Sciences (J.N.), Örebro University, Sweden. 


\section{Glossary}

$\mathbf{A C Z}=$ acetazolamide $; \mathbf{F c}=$ fluorescence density of Alexa Fluor 633 cytoplasm; FDG $=$ fluorodeoxyglucose $; \mathbf{F m}=$ fluorescence density of Alexa Fluor 633 membrane; GOF = gain of function; KCNC3 = potassium voltage-gated channel subfamily C member 3; KCND3 = potassium voltage-gated channel subfamily D member 3; KChIP2 = potassium channel interacting protein 2; LOF = loss of function; SCA = spinocerebellar ataxia; SUD = sudden unexpected death; WT = wild-type.

Heterozygous mutations in potassium voltage-gated channel subfamily D member 3 (KCND3), encoding the voltagedependent potassium channel Kv4.3, are associated with spinocerebellar ataxia (SCA) 19, allelic with SCA22..$^{1-3}$ So far, only 10 articles describing patients with SCA19/22 have been published. ${ }^{2-10}$ The phenotype is variable and includes, besides ataxia, other movement disorders, variable degrees of cognitive impairment and epilepsy. ${ }^{1-10}$ The only fluorodeoxyglucose (FDG) PET study on SCA19 demonstrated widespread hypometabolism. ${ }^{9}$ Genetic variants in $K C N D 3$ are also associated with cardiac arrhythmia and sudden unexpected death (SUD). ${ }^{4,11,12}$

Functional analyses of some of the KCND3 mutations demonstrated either channel dysfunction or reduced cell membrane trafficking. ${ }^{2-5,10,13}$ These abnormalities are often attenuated by co-expression of potassium channel interacting protein 2 (KChIP2). ${ }^{4,5,10,13}$ Here, we report 2 members of a family affected by ataxia and intellectual disability associated with the new V374A variant in KCND3. In addition, the index case suffered from paroxysmal ataxia exacerbations responsive to acetazolamide (ACZ). Our results demonstrate a downscaling of current upon co-expression of wildtype (WT) Kv4.3 with the V374A mutant compared with WT Kv4.3 expressed alone, suggesting a decreased expression of functional channels in the membrane.

\section{Methods}

Both patients provided written and oral consent to this study approved by the ethical committee in Stockholm. Clinical assessment included examination with Scale for Assessment and Rating of Ataxia, Index of Non-Ataxia Symptoms, psychometric testing, and neuroimaging. Neuroimaging included MRI and 18F-FDG PET, whereas psychometric evaluation included a comprehensive test battery (e-Methods, links.lww. com/NXG/A357). The index case was investigated with massive parallel sequencing and candidate variants verified with Sanger sequencing. Injection of complementary RNA encoding channel subunits into Xenopus laevis oocytes and subsequent oocyte voltage-clamp recordings were performed as described previously. ${ }^{14}$ Finally, a computational analysis of the mutational effects of Kv4.3 channels on a Purkinje neuron model was performed using the program NEURON7.7. ${ }^{15,16}$ Briefly, this model incorporates resurgent and nonresurgent Nav channels, Kv1, Kv3, Kv4 channels, P-type calcium channels, calcium-activated $\mathrm{Kv}$ channels, hyperpolarizationactivated cation channels, and leak currents (e-Methods).

\section{Immunocytochemistry}

HEK293T cells were transfected according to previous descriptions, ${ }^{2,3}$ the mean fluorescence density of Alexa Fluor 633 of whole cell body, membrane $(\mathrm{Fm})$, and cytoplasm $(\mathrm{Fc})$, and the $\mathrm{Fm} / \mathrm{Fc}$ ratio was calculated (e-Methods, links.lww. com/NXG/A357).

\section{Data Availability}

Anonymized data will be shared by the investigators upon request.

\section{Results}

\section{Clinical Findings}

Two patients, mother and son, in a Swedish family were diagnosed with adult-onset slowly progressive cerebellar ataxia and bradyphrenia (figure e-1, links.lww.com/NXG/A348). Both patients were also diagnosed with learning difficulties (table 1) and have attended special schools. Common features for these patients include normal general intellectual ability despite low results in cognitive screening tests. Low performance in the following cognitive domains was evident in both patients: information processing speed, visuo-spatial episodic memory, spatial/visual construction, verbal concept formation, phonemic word fluency, and executive function (table 2). Despite these deficits, IQ scores were 90 and 95 , respectively. The index case (II:1) is a 35-year-old man who suffered from paroxysmal ataxia exacerbations when exposed to accelerations/decelerations, such as when riding an elevator, bus, or train. These episodes, witnessed in 2 occasions by 2 of the authors (J.W. and M.P.), were responsive to ACZ. Patient II:1 was also treated with clonazepam and mesalamine, and the latter was for ulcerative colitis. Patient I:1 (62 years old) was not treated with any psychotropic drugs. Cerebellar atrophy was severe in the index case and milder in patient I: 1 ; in both cases, FDG PET demonstrated moderateto-severe hypometabolism in the cerebellum (vermis and upper cerebellar hemispheres) and subtle hypometabolism in the prefrontal cortex (figure e-2, links.lww.com/NXG/A349). We did not find evidence of parkinsonism, epilepsy, polyneuropathy, cardiac signs, or arrhythmias.

\section{Genetic Analyses}

Pathologic CAG expansions associated with SCA 1, 2, 3, 6, 7, dentatorubropallidoluysian atrophy as well as copy number variations were ruled out in the index case. Both patients carry the variants c.1121T $>C(\mathrm{~V} 374 \mathrm{~A})$ in $K C N D 3$ and c.2012T $>\mathrm{C}$ $(\mathrm{A} 671 \mathrm{~V})$ in potassium voltage-gated channel subfamily $\mathrm{C}$ 
Table 1 The Main Features in Both Patients Are Ataxia and Intellectual Disability

\begin{tabular}{|c|c|c|}
\hline Phenotype features & II:1 (index case) & l:1 \\
\hline Axial ataxia & Y & Y \\
\hline Dysarthria & Y & Y \\
\hline $\begin{array}{l}\text { Age at ataxia onset/current } \\
\text { age, y/sex }\end{array}$ & 25/35/M & $46 / 62 / F$ \\
\hline Reflexes & Normal & Normal \\
\hline Cognitive impairment & Y & Y \\
\hline $\begin{array}{l}\text { Impaired smooth pursuit/ } \\
\text { nystagmus }\end{array}$ & $Y / Y$ & $\mathrm{Y} / \mathrm{N}$ \\
\hline Other features & Paroxysmal ataxia exacerbation; increased muscle tone in legs & Mild hand posturing \\
\hline $\begin{array}{l}\text { SARA score at last } \\
\text { examination }\end{array}$ & 13 & 14 \\
\hline EEG & Slow activity in the temporo-parietal regions & Moderate widespread slow activity \\
\hline ENeG & Normal & Normal \\
\hline MRI of the brain & $\begin{array}{l}\text { Marked cerebellar atrophy (vermis and superior part of the } \\
\text { cerebellar hemispheres }\end{array}$ & $\begin{array}{l}\text { Mild atrophy in the cerebellum (vermis) and superior } \\
\text { cerebellar peduncles }\end{array}$ \\
\hline FDG-PET & $\begin{array}{l}\text { Cerebellar hypometabolism; subtle hypometabolism in } \\
\text { prefrontal cortex }\end{array}$ & $\begin{array}{l}\text { Cerebellar hypometabolism; subtle hypometabolism in } \\
\text { prefrontal cortex }\end{array}$ \\
\hline Electrocardiogram & Normal & Normal \\
\hline Comorbidities & Ulcerative colitis & Type 2 diabetes ${ }^{\mathrm{a}}$; hypertonia \\
\hline
\end{tabular}

Abbreviations: $\mathrm{ENeG}=$ electroneurography; $K C N D 3$ = potassium voltage-gated channel subfamily D member 3; SARA = Scale for the Assessment and Rating of Ataxia.

Range or SARA score is $0-40$ points ( $>3$ points indicate ataxia).

This syndrome is associated with the novel c.1121T>C (V374A) in KCND3.

a Treated with metformin and enalapril.

member 3 (KCNC3). The variant c.1121T >C (V374A) in KCND3 has not been reported before, whereas c.2012T $>C$ $(\mathrm{A} 671 \mathrm{~V})$ in $\mathrm{KCNC} 3$ has a minor allele frequency $=0.00016 \%$ in the European population (e-Methods, links.lww.com/ NXG/A357). Heterozygous variants in KCNC3 are associated with SCA13; therefore, we hypothesize a synergistic effect of the $2 \mathrm{~K}+$ channel variants.

\section{In Vitro Studies}

\section{Kv4.3 V374A Disrupts Potassium Conductance}

Oocytes injected with complementary RNA encoding Kv4.3 + KChIP2 (WT:V374A, 1:0) exhibited peaked currents with swift $\mathrm{N}$-type inactivation (figure 1A), consistent with previous descriptions of Kv4.3 currents. ${ }^{17}$ Cells expressing Kv4.3 + Kv4.3 V374A + KChIP2 (WT:V374A, 0.5:0.5) showed smaller currents maintaining the peaked character without shifting the voltage dependence of channel activation (figure 1B) or inactivation (figure e-3, links.lww.com/NXG/A350). In cells expressing Kv4.3 V374A + KChIP2 (WT:V374A, 0:1) alone, virtually no voltage-dependent currents were observed (figure 1C). WT:V374A, 0.5:0.5 demonstrated an average peak current reduction of $\sim 80 \%$ as compared to WT:V374A, 1:0 (figure 1D). A simple scaling effect suggests a reduction of functional Kv4.3 channels in the membrane, with no effect of the V374A mutation on conductance or inactivation curves (figure e-3). Conversely, expression of Kv3.3 + A671V (WT: A671V, 0.5:0.5) resulted in currents similar to those of cells expressing Kv3.3 WT (WT:A671V, 1:0) alone, whereas Kv3.3 A671V (WT:A671V, 0:1) alone exhibited slightly reduced currents compared with WT (figure e-4, links.lww.com/ NXG/A351). Again, for A671V, no effects were observed on activation or inactivation curves (figure e-5, links.lww.com/ NXG/A352). Application of $100 \mu \mathrm{M} \mathrm{ACZ} \mathrm{to} \mathrm{oocytes}$ expressing Kv4.3 + Kv4.3 V374A, 1:0, 0.5:0.5, or 0:1, respectively, did not modify the currents (data not shown).

Kv4.3 Channel Modulates Purkinje Neuron Excitability The effect of reducing the number of functional Kv4.3 channels on neuronal excitability was analyzed using a Purkinje neuron model incorporating $\mathrm{Kv} 1, \mathrm{Kv} 3$, and $\mathrm{Kv} 4$ channels. ${ }^{15}$ Based on the similar kinetic properties of Kv4.3 + Kv4.3 V374A, 1:0 and 0.5:0.5, the maximum Kv4 conductance ( $\mathrm{Kv} 4 \mathrm{bar}$ ) was reduced according to the I-V relationships (figure 1D). In contrast to the WT:V374A, 1:0, the WT: V374A, 0.5:0.5 model demonstrated lower action potential amplitudes and higher firing frequency, indicating modified excitability properties ${ }^{18}$ (figure e-6A, links.lww.com/NXG/ A353). Action potential slope analysis corroborated the 
Table 2 Summary of Cognitive Features in 2 Patients From a Family With SCA19 Associated With the Novel Pathogenic Variant V374A in KCND3

\begin{tabular}{|c|c|c|c|}
\hline \multirow[b]{2}{*}{ Cognitive domain } & \multirow[b]{2}{*}{ Neuropsychological test } & \multirow{2}{*}{$\frac{\mathrm{l}: 1}{\text { At age } 63 \text { (z score) }}$} & \multirow{2}{*}{$\frac{\text { II:1 }}{\text { At age } 35 \text { (z score) }}$} \\
\hline & & & \\
\hline Brief cognitive status examination & MoCA & $12 / 30(-7.0)^{\mathrm{a}}$ & $21 / 30(-2.91)^{a}$ \\
\hline General intellectual ability IQ & Ravens progressive matrices & $19(-0.67) ; 1 Q=90$ & $36(-0.33) ; \mathrm{IQ}=95$ \\
\hline \multirow[t]{2}{*}{ Verbal episodic memory } & RAVLT learning & $14(-4.72)^{\mathrm{a}}$ & $40(-0.83)$ \\
\hline & RAVLT retention & $6(-1.48)$ & $15(1.67)^{a}$ \\
\hline Visuo-spatial episodic memory & ROCFT (delayed recall) & $2(<-3)^{a}$ & $10.5(<-3)^{a}$ \\
\hline Working memory & Digit span/WAIS-III & $4(-2.33)^{a}$ & $9(-1.67)^{a}$ \\
\hline \multirow[t]{2}{*}{ Spatial/visual construction } & ROCFT copy & $3.5(-8.44)^{a}$ & $19.5(-4.30)^{a}$ \\
\hline & Block Design/WAIS-III & $12(-2.0)^{a}$ & $24(-1.33)$ \\
\hline Verbal concept formation & Similarities/WAIS-III & $8(-2.0)^{a}$ & $13(-1.67)^{a}$ \\
\hline Phonemic word fluency & COWAS/FAS & $7(-1.65)^{a}$ & $11(-2.29)^{a}$ \\
\hline Information processing speed & SDMT & $16(-3.56)^{a}$ & $19(-5.41)^{a}$ \\
\hline Executive function & TMT B & $200(<-3.0)^{\mathrm{a}}$ & $394(<-14.0)^{a}$ \\
\hline \multirow[t]{2}{*}{ Motor speed } & FT dominant hand & $5(-3.98)^{a}$ & $44(-0.95)$ \\
\hline & FT nondominant hand & $22(-1.39)$ & $35(-2.18)^{a}$ \\
\hline
\end{tabular}

Abbreviations: COWAT = Controlled Oral Word Association Test; FAS = the letters used in the phonological word fluency test; FT = Finger-tapping test; $K C N D 3=$ potassium voltage-gated channel subfamily D member 3; MoCA = Montreal cognitive assessment; RAVLT= Rey Auditory Verbal Learning Test; ROCFT = ReyOsterrieth Complex Figure Test; SCA = spinocerebellar ataxia; SDMT = Symbol Digit Modalities Test; TMT = Trail Making Test; WAIS-III = Wechsler Adult Intelligence Scale, third edition.

${ }^{\text {a } A ~ z ~ s c o r e ~} \leq-1.5$ SD is compatible with a significant deficit.

dynamic differences induced by WT:V374A, 0.5:0.5, with a slower increase in voltage for the reduced amplitude action potentials (figure e-6B). The firing frequency was increased 2.9-fold by WT:V374A, 0.5:0.5, compared with 1:0, and detailed analysis of peak amplitudes revealed a $22 \mathrm{mV}$ reduction for 0.5:0.5 (figure e-6, C and D). Also, peak width and hyperpolarization were increased for WT:V374A, 0.5:0.5 (figure e-6, E and F).

\section{Immunohistochemistry}

HEK293T cells transiently transfected to express Kv4.3 WT: V374A, 1:0, 0.5:0.5, and 0:1, separately, displayed a high level of $\mathrm{Kv} 4.3$ protein at the cell surface. The $\mathrm{Fm} / \mathrm{Fc}$ ratio of $\mathrm{Kv} 4.3$ WT protein remained at a similar level with or without $\mathrm{Kv} 4.3$ V374A (figure e-7, links.lww.com/NXG/A354).

\section{Discussion}

Paroxysmal ataxia exacerbations responsive to $\mathrm{ACZ}$ and the KCND3 variant V374A are new findings for SCA19. Hypometabolism limited to the cerebellum is unexpected, considering the range of cognitive deficits in this family. These findings contrast with the widespread brain hypometabolism in another SCA19 family. ${ }^{9}$ In our studies, the failure of the Kv4.3 V374A mutant to produce appreciable Kv4.3 currents when expressed alone, along with the conservation of WT channel kinetic properties in the face of a downscaling of current amplitudes, suggests a reduction of functional WT Kv4.3 channels in the membrane upon co-expression with the mutant channel. Our findings neither support a synergistic effect between Kv4.3 V374A and Kv3.3 A671V. However, some caution is required since heterologous expression systems such as Xenopus oocytes may not completely mirror mammalian expression and/or trafficking of ion channels.

Kv4 channels are made of up 4 alpha subunits (figure e-8, links.lww.com/NXG/A355) ${ }^{19}$; thus, incorporation of mutant subunits that are incompatible with channel function can be expected to decrease the number of functional channels by more than 50\% (i.e., a dominant-negative effect). ${ }^{20}$ The Kv4.3 V374A variant is located in the pore loop between transmembrane helices S5 and S6 near the selectivity filter; the part of the protein forming the ion conduction pathway, crucial to the channel's ability to pass current. Of interest the majority of the 13 reported pathogenic variants in KCND3 associated with SCA19 are located in the pore loop or in the nearby extracellular ends of S5 and S6 (figure e-6, links.lww.com/ NXG/A353). Judging by our immunohistochemistry data, V374A appears to be localized to the cell membrane, contrary to other pathogenic KCND3 variants. ${ }^{2,3}$ Despite the relatively conservative amino acid substitution, the V374A variant reduced $\mathrm{Kv} 4.3$ peak currents by $\sim 81 \%$ when co-expressed at a 

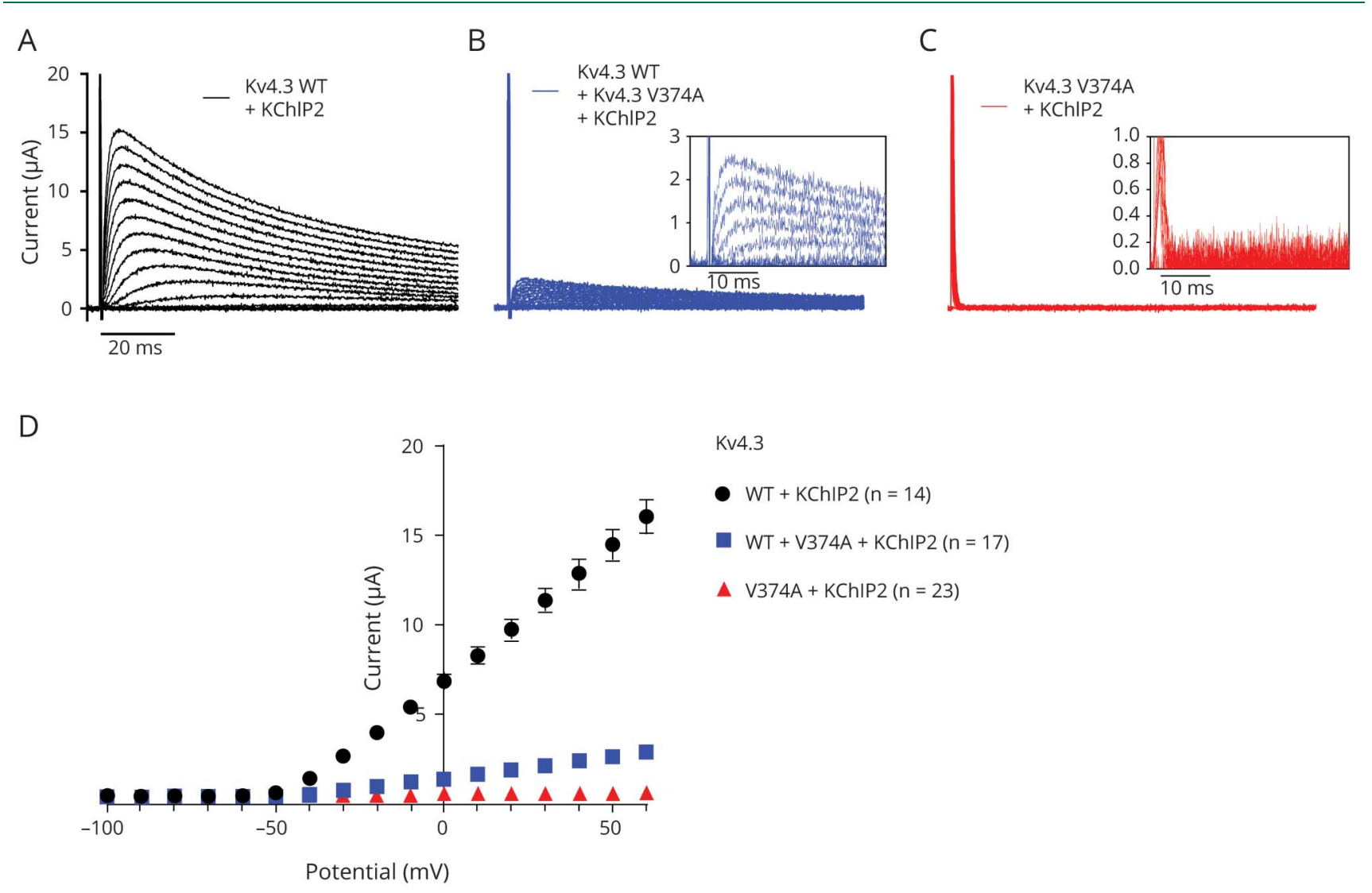

(A) Representative traces of Kv4.3 WT:V374A (1:0). (B) Representative traces of Kv4.3 WT:V374A (0.5:0.5). Inset demonstrates first 40 ms at voltage increments of $20 \mathrm{mV}$ (between -100 and $+60 \mathrm{mV}$ ). (C) Representative traces of WT:V374A (0:1). Inset demonstrates first 40 ms at voltage increments of $20 \mathrm{mV}$ (between -100 and $+60 \mathrm{mV}$ ). (D) I-V relationships for (A-C) measured at the peak current. The holding potential was $-100 \mathrm{mV}$. Voltage steps of $10 \mathrm{mV}$ during $1,000 \mathrm{~ms}$. The interpulse interval was 5 seconds. KChIP2 = potassium channel interacting protein 2; WT = wild-type.

0.5:0.5 ratio with WT Kv4.3 subunits, consistent with a dominant-negative effect. In comparison, the SCA19/22associated $\mathrm{Kv} 4.3 \mathrm{~T} 352 \mathrm{P}$ variant, in the presence of $1: 1$ KChIP2, has been suggested to reduce the peak current by $52 \% .^{13}$ Of interest the adjacent pathogenic variant Kv4.3 M373I, also in the presence of KChIP2, did not affect the expression level in oocytes as measured by current amplitudes. ${ }^{13}$ Given its critical location, it may be that the V374A mutation perturbs the ability of the channel to conduct potassium ions.

KCND3 mutations are also associated with arrhythmia and SUD. We hypothesize that gain-o- function (GOF) variants, reported for SUD, mainly influence the cardiac action potential, whereas loss-of-function (LOF) variants, associated with SCA19/22, mainly modulate neuronal excitability. Purkinje neuron simulations with a $80 \%$ reduction of $\mathrm{Kv} 4.3$ channel conductance (e.g., 0.5:0.5, WT:V374A) demonstrated rapid firing, whereas corresponding simulations with only a slightly increased Kv4.3 channel conductance (103\%; corresponding to GOF mutations) demonstrate reduced firing frequencies (and no firing with further increased Kv4 conductance). The increase in firing frequency following
Kv4.3 inhibition is in line with previous pharmacologic and genetic experiments with dopamine ${ }^{21}$ and pyramidal neurons, respectively. $^{22}$ By contrast, a ventricular cell model ${ }^{23}$ exhibited slightly shortened action potentials following $\sim 80 \%$ reduction in the number of $\mathrm{Kv} 4$ channels, whereas a 50\%-100\% increase in $\mathrm{Kv} 4$ channels, corresponding to GOF variants, prolonged the action potentials substantially ${ }^{11}$ (figure e-9, links.lww.com/NXG/A356). Hypothetically, KChIP2 may be involved in regulating the $\mathrm{Kv} 4.3$ expression in pathologic conditions - for GOF (LOF) variants, reduced (increased) KChIP2 levels may decrease (increase) the number of Kv4.3 channels. Theoretically, such differences may explain why concomitant ataxia and arrhythmia have not been reported. Expression of KChIP2 has recently been demonstrated to modulate the balance between Kv4.3 and voltage-gated sodium channel 5 (Nav1.5). ${ }^{24}$ However, the GOF variant Kv4.3 L450F has been reported separately in a patient with Brugada syndrome $^{25}$ and a patient with ataxia, ${ }^{4}$ illustrating the complexity in elucidating genotype-phenotype correlations for KCND3.

Although ACZ demonstrated clinical efficacy in the index case, no in vitro effects were observed on Kv4.3 V374A. 
Instead, carbonic anhydrase inhibition by $\mathrm{ACZ}$ and subsequent $\mathrm{pH}$ reduction could indirectly modulate ion channels, thereby possibly mediating the therapeutic effect and attenuating paroxysmal ataxia exacerbations. Decreased neuronal excitability in numerous SCAs associated with LOF variants (SCA27-indirectly Nav1.6, SCA13-Kv3.3, and SCA6Cav2.1) has been described. ${ }^{26}$ For Kv4.3 LOF, increased Purkinje neuron excitability was observed in the simulations. Based on this, evaluation of drugs reducing neuronal excitability, e.g., Nav channel blockers, in a Kv4.3 LOF model may provide further insights of therapeutic relevance.

\section{Acknowledgment}

The authors are grateful to the patients for their kind participation in this study. They are also grateful to the Follin Foundation for supporting M. Paucar's research.

\section{Study Funding}

The authors report no targeted funding.

\section{Disclosure}

The authors report no disclosures relevant to the manuscript. Go to Neurology.org/NG for full disclosures.

\section{Publication History}

Received by Neurology: Genetics August 27, 2020. Accepted in final form October 27, 2020.

\section{Appendix Authors}

\begin{tabular}{|c|c|c|}
\hline Name & Location & Contribution \\
\hline $\begin{array}{l}\text { Martin Paucar, } \\
\text { MD, PhD }\end{array}$ & $\begin{array}{l}\text { Karolinska University } \\
\text { Hospital and Karolinska } \\
\text { Institutet, Stockholm, } \\
\text { Sweden }\end{array}$ & $\begin{array}{l}\text { Patient care; study concept } \\
\text { and design; analysis and } \\
\text { interpretation of data; } \\
\text { drafting and revising the } \\
\text { manuscript }\end{array}$ \\
\hline $\begin{array}{l}\text { Richard Ågren, } \\
\text { MD, PhD }\end{array}$ & $\begin{array}{l}\text { Karolinska University } \\
\text { Hospital and Karolinska } \\
\text { Institutet, Stockholm, } \\
\text { Sweden }\end{array}$ & $\begin{array}{l}\text { Study concept and design; } \\
\text { electrophysiologic } \\
\text { experiments; Purkinje } \\
\text { neuron firing model and } \\
\text { data analyses; drafting and } \\
\text { revising the manuscript }\end{array}$ \\
\hline Tianyi Li, PhD & $\begin{array}{l}\text { Astrid Lindgren's Hospital, } \\
\text { Stockholm, Sweden }\end{array}$ & $\begin{array}{l}\text { Immunohistochemistry; } \\
\text { revising the manuscript }\end{array}$ \\
\hline $\begin{array}{l}\text { Simon } \\
\text { Lissmats }\end{array}$ & $\begin{array}{l}\text { Karolinska Institutet, } \\
\text { Stockholm, Sweden }\end{array}$ & $\begin{array}{l}\text { Electrophysiologic } \\
\text { experiments; revising the } \\
\text { manuscript }\end{array}$ \\
\hline $\begin{array}{l}\text { Åsa Bergendal, } \\
\text { PhD }\end{array}$ & $\begin{array}{l}\text { Karolinska University } \\
\text { Hospital and Karolinska } \\
\text { Institutet, Stockholm, } \\
\text { Sweden }\end{array}$ & $\begin{array}{l}\text { Acquisition and } \\
\text { interpretation of } \\
\text { cognitive evaluations; } \\
\text { revising the manuscript }\end{array}$ \\
\hline $\begin{array}{l}\text { Jan Weinberg, } \\
\text { MD, PhD }\end{array}$ & $\begin{array}{l}\text { Karolinska University } \\
\text { Hospital and Karolinska } \\
\text { Institutet, Stockholm, } \\
\text { Sweden }\end{array}$ & $\begin{array}{l}\text { Acquisition and } \\
\text { interpretation of clinical } \\
\text { data, patient care; } \\
\text { revising the manuscript }\end{array}$ \\
\hline $\begin{array}{l}\text { Daniel Nilsson, } \\
\text { PhD }\end{array}$ & $\begin{array}{l}\text { Karolinska University } \\
\text { Hospital and Karolinska } \\
\text { Institutet, Stockholm, } \\
\text { Sweden }\end{array}$ & $\begin{array}{l}\text { Obtaining and } \\
\text { interpretation of genetic } \\
\text { data; revising the } \\
\text { manuscript }\end{array}$ \\
\hline
\end{tabular}

Appendix (continued)

\begin{tabular}{|c|c|c|}
\hline Name & Location & Contribution \\
\hline $\begin{array}{l}\text { Irina } \\
\text { Savichetva, } \\
\text { MD, PhD }\end{array}$ & $\begin{array}{l}\text { Karolinska University } \\
\text { Hospital and Karolinska } \\
\text { Institutet, Stockholm, } \\
\text { Sweden }\end{array}$ & $\begin{array}{l}\text { Obtaining and } \\
\text { interpreting } \\
\text { neuroimaging data; } \\
\text { revising the manuscript }\end{array}$ \\
\hline $\begin{array}{l}\text { Kristoffer } \\
\text { Sahlholm, PhD }\end{array}$ & Umeå University, Sweden & $\begin{array}{l}\text { Design, analysis and } \\
\text { interpretation of } \\
\text { electrophysiologic data; } \\
\text { revising the manuscript; } \\
\text { editing of the final } \\
\text { manuscript version }\end{array}$ \\
\hline $\begin{array}{l}\text { Johanna } \\
\text { Nilsson, MD, } \\
\text { PhD }\end{array}$ & $\begin{array}{l}\text { Karolinska University } \\
\text { Hospital and Karolinska } \\
\text { Institutet, Stockholm, } \\
\text { Sweden }\end{array}$ & $\begin{array}{l}\text { Study concept and } \\
\text { design; analysis and } \\
\text { interpretation of data, } \\
\text { drafting and revising the } \\
\text { manuscript; editing of the } \\
\text { final manuscript version }\end{array}$ \\
\hline $\begin{array}{l}\text { Per } \\
\text { Svenningsson, } \\
\text { MD, PhD }\end{array}$ & $\begin{array}{l}\text { Karolinska University } \\
\text { Hospital and Karolinska } \\
\text { Institutet, Stockholm, } \\
\text { Sweden }\end{array}$ & $\begin{array}{l}\text { Study concept and } \\
\text { design; analysis and } \\
\text { interpretation of data, } \\
\text { drafting and revising the } \\
\text { manuscript; editing of the } \\
\text { final manuscript version }\end{array}$ \\
\hline
\end{tabular}

\section{References}

1. Schelhaas HJ, Ippel PF, Hageman G, et al. Clinical and genetic analysis of a fourgeneration family with a distinct autosomal dominant cerebellar ataxia. J Neurol 2001 248:113-120. doi: 10.1007/s004150170245.

2. Duarri A, Jezierska J, Fokkens M, et al. Mutations in potassium channel kcnd3 cause spinocerebellar ataxia type 19. Ann Neurol 2012;72:870-880. doi: 10.1002/ana. 23700 .

3. Lee YC, Durr A, Majczenko K, et al. Mutations in KCND3 cause spinocerebellar ataxia type 22. Ann Neurol 2012;72:859-869. doi: 10.1002/ana.23701.

4. Duarri A, Nibbeling E, Fokkens MR, et al. The L450F [Corrected] mutation in KCND3 brings spinocerebellar ataxia and Brugada syndrome closer together. Neurogenetics 2013;14:257-258. doi: 10.1007/s10048-013-0370-0.

5. Smets K, Duarri A, Deconinck T, et al. First de novo KCND3 mutation causes severe Kv4.3 channel dysfunction leading to early onset cerebellar ataxia, intellectual disability, oral apraxia and epilepsy. BMC Med Genet 2015;16:51. doi: 10.1186/s12881-015-0200-3.

6. Coutelier M, Coarelli G, Monin ML, et al. A panel study on patients with dominan cerebellar ataxia highlights the frequency of channelopathies. Brain 2017;140: 1579-1594. doi: 10.1093/brain/awx081.

7. Huin V, Strubi-Vuillaume I, Dujardin K, et al. Expanding the phenotype of SCA19/ 22: parkinsonism, cognitive impairment and epilepsy. Parkinsonism Relat Disord 2017;45:85-89. doi: 10.1016/j.parkreldis.2017.09.014.

8. Kurihara M, Ishiura H, Sasaki T, et al. Novel de novo KCND3 mutation in a Japanese patient with intellectual disability, cerebellar ataxia, myoclonus, and dystonia. Cerebellum 2018;17:237-242. doi: 10.1007/s12311-017-0883-4.

9. Paucar M, Bergendal $\AA$, Gustavsson P, et al. Novel features and abnormal pattern of cerebral glucose metabolism in spinocerebellar ataxia 19. Cerebellum 2018;17: 465-476. doi: 10.1007/s12311-018-0927-4.

10. Hsiao CT, Fu SJ, Liu YT, et al. Novel SCA19/22-associated KCND3 mutations disrupt human KV 4.3 protein biosynthesis and channel gating. Hum Mutat 2019;40: 2088-2107. doi: 10.1002/humu.23865.

11. Giudicessi JR, Ye D, Kritzberger CJ, et al. Novel mutations in the KCND3-encoded $\mathrm{Kv} 4.3 \mathrm{~K}+$ channel associated with autopsy-negative sudden unexplained death. Hum Mutat 2012;33:989-997. doi: 10.1002/humu.22058.

12. Takayama K, Ohno S, Ding WG, et al. A de novo gain-of-function KCND3 mutation in early repolarization syndrome. Heart Rhythm 2019;16:1698-1706. doi: 10.1016/j. hrthm.2019.05.033.

13. Duarri A, Lin MC, Fokkens MR, et al. Spinocerebellar ataxia type 19/22 mutations alter heterocomplex Kv4.3 channel function and gating in a dominant manner. Cell Mol Life Sci 2015;72:3387-3399. doi: 10.1007/s00018-015-1894-2.

14. Papke RL, Stokes C. Working with OpusXpress: methods for high volume oocyte experiments. Methods 2010;51:121-133. doi: 10.1016/j.ymeth.2010.01.012.

15. Akemann $\mathrm{W}, \mathrm{Knöpfel} \mathrm{T}$. Interaction of $\mathrm{Kv} 3$ potassium channels and resurgent sodium current influences the rate of spontaneous firing of Purkinje neurons. J Neurosci 2006; 26:4602-4612. doi: 10.1523/JNEUROSCI.5204-05.2006.

16. Carnevale NT, Hines ML. The NEURON Book. Cambridge: Cambridge University Press; 2006

17. Patel SP, Campbell DL, Strauss HC. Elucidating KChIP effects on Kv4.3 inactivation and recovery kinetics with a minimal KChIP2 isoform. J Physiol 2002;545:5-11. doi: 10.1113/jphysiol.2002.031856. 
18. Izhikevich EM. Dynamical Systems in Neuroscience. Cambridge: MIT Press; 2007.

19. Parcej DN, Scott VE, Dolly JO. Oligomeric properties of alpha-dendrotoxin-sensitive potassium ion channels purified from bovine brain. Biochemistry 1992;31: 11084-11088. doi: 10.1021/bi00160a018.

20. Herskowitz I. Functional inactivation of genes by dominant negative mutations. Nature 1987;329:219-222. doi: 10.1038/329219a0.

21. Liss B, Franz O, Sewing S, Bruns R, Neuhoff H, Roeper J. Tuning pacemaker frequency of individual dopaminergic neurons by Kv4.3L and KChip3.1 transcription. EMBO J 2001;20:5715. doi: 10.1093/emboj/20.20.5715.

22. Carrasquillo Y, Burkhalter A, Nerbonne JM. A-type K+ channels encoded by Kv4.2, $\mathrm{Kv} 4.3$ and Kv1.4 differentially regulate intrinsic excitability of cortical pyramidal neurons. J Physiol 2012;590:3877-3890. doi: 10.1113/jphysiol.2012.229013.
23. Hund TJ, Rudy Y. Rate dependence and regulation of action potential and calcium transient in a canine cardiac ventricular cell model. Circulation 2004;110:3168-3174. doi: 10.1161/01.CIR.0000147231.69595.D3.

24. Clatot J, Neyroud N, Cox R, et al. Inter-regulation of K(v)4.3 and voltage-gated sodium channels underlies predisposition to cardiac and neuronal channelopathies. Int J Mol Sci 2020;21:4908. doi: 10.3390/ijms21144908.

25. Giudicessi JR, Ye D, Tester DJ, et al. Transient outward current (I(to)) gain-offunction mutations in the KCND3-encoded Kv4.3 potassium channel and Brugada syndrome. Heart Rhythm 2011;8:1024-1032. doi: 10.1016/j.hrthm.2011.02.021.

26. Hoxha E, Balbo I, Miniaci MC, et al. Purkinje cell signaling deficits in animal models of ataxia. Front Synaptic Neurosci 2018;10:6. doi: 10.3389/fnsyn.2018.00006. 


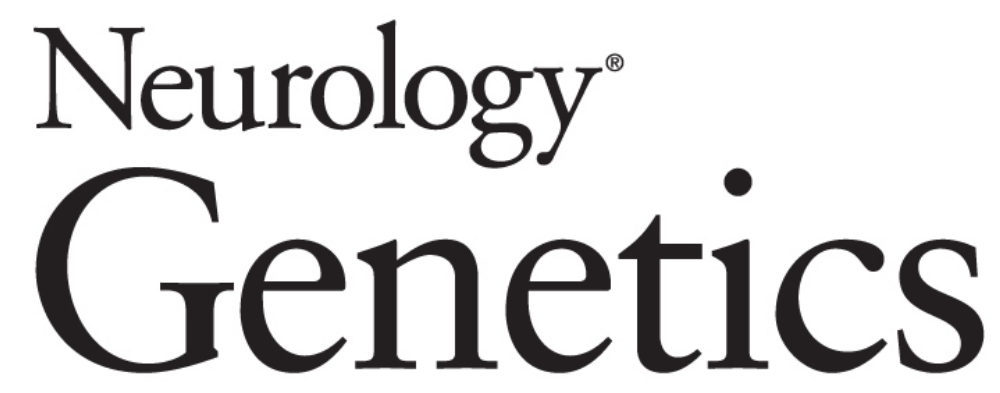

V374A KCND3 Pathogenic Variant Associated With Paroxysmal Ataxia Exacerbations Martin Paucar, Richard Ågren, Tianyi Li, et al. Neurol Genet 2021;7;

DOI 10.1212/NXG.0000000000000546

This information is current as of January 6, 2021

Neurol Genet is an official journal of the American Academy of Neurology. Published since April 2015, it is an open-access, online-only, continuous publication journal. Copyright Copyright ( 2021 The Author(s). Published by Wolters Kluwer Health, Inc. on behalf of the American Academy of Neurology.. All rights reserved. Online ISSN: 2376-7839.

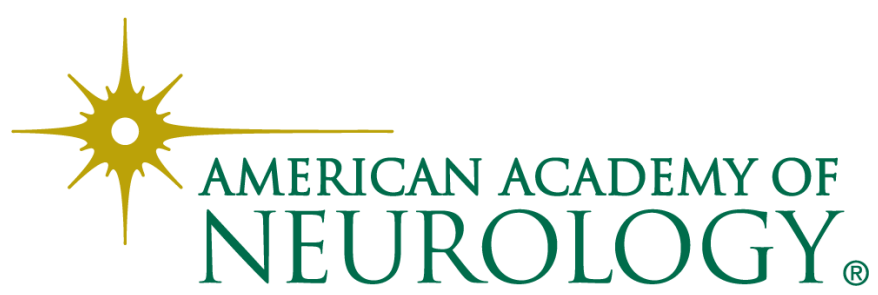




\section{Updated Information \& Services}

References

Citations

Subspecialty Collections

Errata

Permissions \& Licensing

\section{Reprints}

including high resolution figures, can be found at: http://ng.neurology.org/content/7/1/e546.full.html

This article cites 24 articles, 3 of which you can access for free at: http://ng.neurology.org/content/7/1/e546.full.html\#\#ref-list-1

This article has been cited by 2 HighWire-hosted articles: http://ng.neurology.org/content/7/1/e546.full.html\#\#otherarticles

This article, along with others on similar topics, appears in the following collection(s):

\section{All Movement Disorders}

http://ng.neurology.org//cgi/collection/all_movement_disorders Ion channel gene defects

http://ng.neurology.org//cgi/collection/ion_channel_gene_defects

An erratum has been published regarding this article. Please see next page or:

/content/7/2/e567.full.pdf

Information about reproducing this article in parts (figures,tables) or in its entirety can be found online at:

http://ng.neurology.org/misc/about.xhtml\#permissions

Information about ordering reprints can be found online:

http://ng.neurology.org/misc/addir.xhtml\#reprintsus

Neurol Genet is an official journal of the American Academy of Neurology. Published since April 2015, it is an open-access, online-only, continuous publication journal. Copyright Copyright $\odot 2021$ The Author(s). Published by Wolters Kluwer Health, Inc. on behalf of the American Academy of Neurology.. All rights reserved. Online ISSN: 2376-7839.

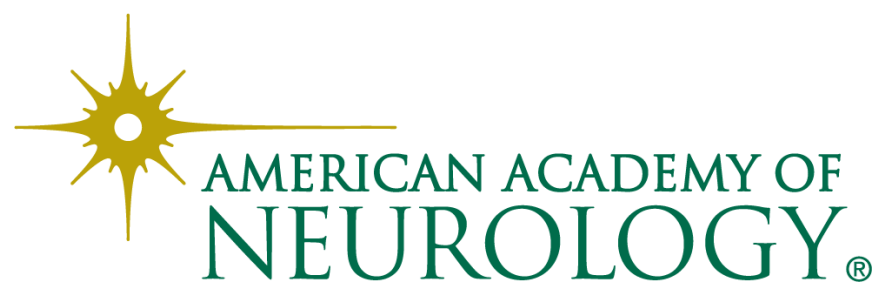




\section{V374A KCND3 Pathogenic Variant Associated With Paroxysmal}

\section{Ataxia Exacerbations}

Neurol Genet 2021;7:e567. doi:10.1212/NXG.0000000000000567

In the article "V374A KCND3 Pathogenic Variant Associated With Paroxysmal Ataxia Exacerbations" by Paucar et al., the eighth author's name should read "Irina Savitcheva." Additionally, the order of authors in the byline should be as follows: Martin Paucar, Richard Ågren, Tianyi Li, Simon Lissmats, Åsa Bergendal, Jan Weinberg, Daniel Nilsson, Irina Savitcheva, Kristoffer Sahlholm, Per Svenningsson, and Johanna Nilsson. The authors regret the errors.

\section{Reference}

1. Paucar M, Ågren R, Li T, et al. V374A KCND3 pathogenic variant associated with paroxysmal ataxia exacerbations. Neurol Genet 2021; 7:e546. doi: 10.1212/NXG.0000000000000546. 